\title{
Does incomplete excision of basal cell carcinoma of the eyelid mean tumor recurrence?*
}

\section{A excisão incompleta de carcinoma basocelular da pálpebra implica} em recidiva do tumor?

\author{
Irena Jankovic ${ }^{1}$ \\ Milan Visnjic ${ }^{3}$ \\ Ivana Binic ${ }^{5}$
}

\author{
Predrag Kovacevic ${ }^{2}$ \\ Dimitrije Jankovic ${ }^{4}$ \\ Aleksandar Jankovic ${ }^{6}$
}

\begin{abstract}
Introduction: Basal cell carcinoma is the most common tumor of the eyelid. In this region, reconstruction is complex and damage to healthy tissue should be minimal. Objective: To define the relationship between margin clearance at excision and the recurrence rate of basal cell carcinoma of the eyelid.

Methods: This prospective study was conducted with 111 patients submitted to surgery for basal cell carcinoma of the eyelid between 2001 and 2003 and followed up for a period of five years. The patients were evaluated according to age, tumor site, recurrence rate and margin clearance at excision.

Results: No significant association was found between incomplete tumor excision and recurrence except in patients under 56 years of age, female patients and in the case of tumors of the medial canthus.

Conclusion: A risk of recurrence in incompletely excised basal cell carcinomas of the eyelid was only confirmed in younger patients, females and for tumors of the medial canthus.

Keywords: Basal cell carcinoma; eyelid; recurrence.

Resumo: Introdução: O carcinoma basocelular é o tumor mais comum entre os tumores das pálpebras. Nesta região, a reconstrução é complexa e recomenda-se que haja perda mínima de tecido saudável. Objetivo: Para definir a relação entre margem livre de tumor na excisão e taxa de recidiva do carcinoma basocelular das pálpebras.

Métodos: Este estudo prospectivo incluiu 111 pacientes operados para remoção de carcinoma basocelular das pálpebras no período de 2001 a 2003, com acompanhamento subsequente de 5 anos. Os pacientes foram avaliados de acordo com a idade, localização do tumor, taxa de recidiva, e margem livre de tumor na excisão.

Resultados: Não se encontrou associação significativa entre a excisão incompleta do tumor e casos de recidiva, exceto em pacientes com idade inferior a 56 anos, pacientes do sexo feminino e em tumores do canto medial.

Conclusão: Um risco maior de recidiva de carcinoma basocelular das pálpebras com excisão incompleta foi confirmado estatisticamente apenas em pacientes mais jovens, em mulheres, e nos tumores do canto interno.

Palavras-chave: Carcinoma basocelular; Pálpebras; Recidiva
\end{abstract}

\footnotetext{
Aproved by the advisory board and accepted for publication on 16.03.2010.

* Study conducted at The Clinical Center Nis, Serbia and University Synergy Banja Luka, Bosnia and Herzegovina Conflito de interesse: Nenhum / Conflict of interest: None Suporte financeiro: Nenhum / Financial funding: None

Plastic and reconstructive surgeon, Master of Science, Assistant Surgeon. Plastic and Reconstructive Surgery Clinic, Clinical Center Nis, Serbia Plastic and reconstructive surgeon, Ph.D., Assistant Professor. Plastic and Reconstructive Surgery Clinic, Clinical Center Nis, Serbia. Plastic and reconstructive surgeon, Ph.D., Professor. Plastic and Reconstructive Surgery Clinic, Clinical Center Nis, Serbia.

Internist, Ph.D., Assistant Professor. School of Cosmetology and Esthetics, Department of Pathology, University Synergy Banja Luka, Bosnia and Herzegovina.

Dermatologist, Ph.D., Professor. Dermatology Clinic, Clinical Center Nis, Serbia

Dermatologist, Ph.D., Assistant Professor. Dermatology Clinic, Clinical Center Nis, Serbia.

(C)2010 by Anais Brasileiros de Dermatologia
} 


\section{INTRODUCTION}

Basal cell carcinoma (BCC) is the most common skin malignancy of the eyelids and although metastases are extremely rare, advanced local invasion may cause significant and sometimes severe morbidity. ${ }^{1}$ Ninety percent of all BCC in the periorbital region are situated on the lower eyelid or in the medial canthal region. ${ }^{2}$ A diagnosis of $\mathrm{BCC}$ is based on clinical findings and confirmed by subsequent histopathology. ${ }^{3}$

BCC may be treated using a variety of methods that include electrodesiccation, curettage, cryotherapy, Mohs micrographic surgery, radiation therapy, topical immunomodulators, photodynamic therapy and surgical excision. ${ }^{4}$ Surgery is the principal form of treatment used. ${ }^{5}$ At excision of the BCC, clinically clear margins of 3-4 mm must be left and primary repair of the defect should be performed. ${ }^{6}$ When the eyelid margin is involved, the defect resulting from the operation often requires sophisticated reconstructive surgery because direct closure is inadequate. Primary suture in layers can only be performed in the case of small lesions. However, in many patients, excision of the BCC including clinically clear $4 \mathrm{~mm}$ margins results in the removal of a significant quantity of normal tissue. ${ }^{7}$ Achieving the best functional and cosmetic results is important in order to minimize the amount of normal tissue lost. On the other hand, ${ }^{3 \cdot 4} \mathrm{~mm}$ margins are insufficient to guarantee a complete, histologically proven excision in up to $54 \%$ of cases. ${ }^{8}$ Incomplete excision was defined as the presence of tumor tissue at the margins of resection in the final histological report. ${ }^{9}$

Incomplete excision is most commonly associated with tumors situated on the nose and inner canthus. ${ }^{5}$ There appears to be a certain difficulty in assessing these regions clinically, and also pathologically, when taking spatial orientation, thin skin, fragmentation of margins and tissue shrinkage after formalin fixation into account. ${ }^{10}$

Incomplete resection of a BCC does not necessarily imply tumor recurrence. ${ }^{11}$ Possible reasons for non-recurrence may include an immune reaction, inflammation or devitalization of the residual tumor tissue. $^{12}$

Indeed, some investigators have reported that after a 5 or 10-year follow-up period, not all incompletely excised BCC resulted in recurrences. The highest recurrence rate in BCC was recorded two years after surgery. ${ }^{13}$ These reports favor a conservative "wait and see" policy that includes the need for conscientious postoperative follow-up. ${ }^{14}$

Management of incompletely excised BCC remains a matter of debate. ${ }^{15}$ Nevertheless, it is important to preserve as much normal tissue as possible, particularly in the periocular region, thus optimizing the possibility of achieving good esthetic results with mini- mal intervention. ${ }^{16}$ With the objective of preserving tissue, while avoiding reoperating an incompletely excised periorbital BCC, the present study evaluated whether residual tumor tissue is indicative of tumor recurrence, what the risk factors for recurrence are, and the most probable timing of a diagnosis of recurrence, in order to ensure that only those for whom reoperation is mandatory are subjected to further surgery.

\section{PATIENTS AND METHODS}

This prospective study was conducted in patients with periocular BCC treated by surgical excision at a tertiary clinic between 2001 and 2003. Followup was conducted over a period of at least five years.

The excision line was measured and marked at a distance of 3-4 $\mathrm{mm}$ from the tumor edge. Standard excision techniques were used with minimal disruption of the edges of the sample, which was subsequently fixed in formalin and paraffin-embedded. The reconstruction technique was defined in accordance with the size and site of the defect, and included primary closure, skin grafts or flaps. In those cases in which the surgical margins were affected by tumor cells, postoperative monitoring was the only approach used.

The following characteristics were analyzed: whether or not the excision was complete, tumor recurrence, tumor site (upper / lower eyelid or medial / lateral canthal region), and the gender and age of the patient.

The SPSS statistical software package, version 15.0, and the EpiInfo Statcalc program, version 5.0, were used in the statistical analysis. The following statistical tests were performed: the KolmogorovSmirnov and Shapiro-Wilk tests of normality, the chisquare test, Fisher's exact test, the Mann-Whitney U test and univariate logistic regression. Results are presented as odds ratios with their $95 \%$ confidence intervals. The 5-year cumulative probabilities of BCC recurrence in the two groups (the group in which the tumor had been completely excised and the group in which excision had been incomplete) were compared using Kaplan-Meier survival analysis and log rank test, analyzing the difference between the observed and expected number of recurrences at each of the time points. P-values $<0.05$ were considered significant.

\section{RESULTS}

A total of 111 patients with BCC were treated between 2001 and 2003 and followed up over a fiveyear period. Of the 111 excised tumors, margins were negative in $90(81.08 \%)$ and positive in 21 (18.92\%).

The mean age of the patients at the time of treatment was $67.03 \pm 8.23$ years (range 28-93 years). In the case of the completely excised tumors, the 
mean age of the patients who had a recurrence of the tumor was lower compared to those who did not have a recurrence, and this difference was statistically significant $(57.61$ versus 68.23 years; Mann-Whitney U test, $p=0.002)$. In addition, the mean age of the patients with positive margins and recurrence (56.6 years) was significantly lower than the mean age of 66.12 years of the patients with an incompletely excised tumor who had no recurrence (Mann-Whitney $\mathrm{U}$ test, $\mathrm{p}=0.028$ ).

The male-to-female gender ratio was 1.22 . Of the 48 male patients in whom margins were negative, recurrence was found in 3 cases, while of the 13 men in whom margins were positive, only one recurrence occurred. Of the 42 female patients with negative margins, there was a recurrence in 6 , while of the 8 female patients with positive margins there were 4 recurrences. A statistically significant difference between incomplete tumor excision and recurrence was found only in the case of female patients (Fisher's test, $\mathrm{p}=0.041$ ).

The most common site of the BCC was on the lower eyelid ( 57 patients), followed by the medial canthus region (38 patients), upper eyelid (14 patients), and, least commonly, in the lateral canthus region (2 patients). Tumor site was significantly associated with recurrence. Most of the recurrences recorded during the study occurred on the medial canthus (9/38 tumors; $23.68 \%$ ), upper eyelid (3/14 tumors; $21.43 \%$ ) or lower eyelid (2/57 tumors; $3.51 \%)$, with no recurrences in the lateral canthus (chi-square test, $\mathrm{p}=0.02$ ).

Of the various periorbital sites of BCC, a statistically significant correlation was found between incomplete tumor excision and recurrence only in the case of malignancies situated in the medial canthus. Recurrence was found in 5/31 tumors with negative margins and in 4/7 tumors with positive margins (Fisher's exact test, $\mathrm{p}=0.041$ ). The OR value of 6.93 (95\%CI: 0.9-60.73) was significant only for BCC in the medial canthal region. The risk of recurrence in the case of incompletely excised tumors in the medial canthus was 6.93 times higher than that of completely excised tumors in this same region (Table 1).

Overall, there was a recurrence in 14 cases of BCC, 9 of which occurred in patients with negative margins and 5 in patients with positive margins. The 5-year probability of recurrence, calculated using Kaplan-Meier survival analysis, was $23.8 \%$ for incompletely excised BCC and 10\% for completely excised BCC; however, this difference was not statistically significant (log rank test, $p=0.075$, Figure 1 ).

The numbers of recurrences per year are shown for both groups in table 2 . In the first year following surgery, recurrence was found in only one case in the group of patients in whom the tumors had been com- pletely excised (90 patients), while three recurrences were found in the second year and one in the fourth year. In the fifth year following surgery, no further recurrences were found. In patients with incompletely excised tumors ( 21 patients), there was one recurrence in the first year following surgery, two in the second year and another two in the third year, while in the fourth and fifth years of follow-up there were no further recurrences.

\section{DISCUSSION}

BCC of the eyelid is the most common form of malignancy encountered in ophthalmic practice. ${ }^{17}$ According to Griffiths, ${ }^{10} 7 \%$ of cases of BCC in his study were found to be incompletely excised, as confirmed by histological examination. Kumar et al. ${ }^{18}$ conducted a 1-year prospective study and reported that 34 out of 757 cases of BCC (4-5\%) had been incompletely excised. In a study conducted by Wilson et al., ${ }^{19} 6.2 \%$ of cases of BCC of the head or neck were incompletely excised. In the case of periorbital lesions, the overall rate of incomplete excision was $13 \%$ (range $11-17 \%$ ) $;^{10}$ however, in the present study positive margins were diagnosed in $18.92 \%$. In Wilson's study, the risk of incomplete excision was higher when the tumors were located in the medial canthus or lower eyelid (risk $>10 \%) .{ }^{19}$ In the present study, incomplete excision was most common in the medial canthus region (10.51\%). In addition, Pieh et al. ${ }^{20}$ reported that the risk of subsequent recurrence at most of these sites was about $30 \%$.

Previous studies found recurrence rates $<10 \%$ in cases of incompletely excised, nonaggressive BCC. ${ }^{21,22}$ Boulinguez et al. ${ }^{15}$ reported a low recurrence rate in initially nonaggressive cases of BCC, with an aggressive component found in $20 \%$ of cases. The probability of recurrence in cases of incompletely resected $\mathrm{BCC}$ ranges from $30 \%$ to $50 \%$, as reported in other studies. ${ }^{14}$ Based on the fact that in $41 \%$ of re-excisions no residual tumor tissue was detected, incomplete excision of BCC does not appear to be synonymous with the persistence of residual tumor tissue. ${ }^{23}$ Wilson et al. ${ }^{19}$ found residual tumor tissue in $45 \%$ of re-excised specimens. These investigators implemented a "wait and see policy" and reported recurrences in $21 \%$ of cases. In the present study, disease recurrence within the 5-year follow-up period was recorded in only $23.81 \%$ of the patients with positive margins.

Residual tumor tissue was found in only 4 of the 16 re-excisions in the periorbital region. ${ }^{19}$ The likelihood of finding residual tumor tissue in periorbital lesions is low, with the exception of the inner canthus. ${ }^{10}$ In the present study, recurrences were most common in the medial canthus region $(23.68 \%)$. A significant association between incomplete tumor 
TABLE 1: Clinicopathological characteristics of the study groups

\begin{tabular}{|c|c|c|c|c|c|}
\hline \multirow[b]{3}{*}{ Mean age \pm SD } & \multicolumn{2}{|c|}{$\begin{array}{l}\text { Group I - with negative } \\
\text { margins }(n=90)\end{array}$} & \multicolumn{2}{|c|}{$\begin{array}{l}\text { Group II - with positive } \\
\text { margins }(n=21)\end{array}$} & \multirow{3}{*}{$\begin{array}{l}\text { TOTAL } \\
67.03 \pm 8.23\end{array}$} \\
\hline & No recurrence & Recurrence & No recurrence & Recurrence & \\
\hline & $68.23 \pm 9.42$ & $57.61 \pm 7.25+$ & $66.12 \pm 7.89$ & $56.6 \pm 5.7+$ & \\
\hline \multicolumn{6}{|l|}{ Age (years) } \\
\hline$\leq 45$ & 1 & 1 & 1 & 1 & 4 \\
\hline $46-55$ & 3 & 2 & 1 & 2 & 8 \\
\hline $56-65$ & 6 & 3 & 1 & 1 & 11 \\
\hline $66-75$ & 34 & 1 & 6 & 1 & 42 \\
\hline$>75$ & 37 & 2 & 7 & 0 & 46 \\
\hline \multicolumn{6}{|l|}{ Gender } \\
\hline Male & 45 & 3 & 12 & 1 & 61 \\
\hline Female & 36 & 6 & 4 & $4 *$ & 50 \\
\hline \multicolumn{6}{|l|}{ Anatomical site } \\
\hline Medial canthal region & 26 & 5 & 3 & $4^{*}$ & 38 \\
\hline Lateral canthal region & 2 & 0 & 0 & 0 & 2 \\
\hline Upper lid & 6 & 2 & 5 & 1 & 14 \\
\hline Lower lid & 47 & 2 & 8 & 0 & 57 \\
\hline
\end{tabular}

* Group I versus Group II, $\mathrm{p}<0.05$

+ No recurrence versus recurrence, $\mathrm{p}<0.05$

excision and recurrence was found only when the tumor was situated in the medial canthus. The risk of subsequent recurrence in the case of incompletely excised tumors at this site was 6.93 times higher than that of completely excised neoplasms.

One explanation of why there were no clinical recurrences in the earlier studies may have been that the tumor tissue present at the margins was devitalized during the surgical procedure, e.g. by electrocautery, disappearing after surgery. ${ }^{14}$ Spontaneous regression of residue BCC at the margin has been reported ${ }^{24}$ and was thought to be related to the presence of a weak host response mediated by lymphocytes infiltrating the tumor. ${ }^{25}$ Other investigators ${ }^{26,27}$ have reported that residual BCC was present in $37 \%$ of patients after treatment with curettage and electrodesiccation, and that there was no sign of regression after 1 and 3 months.

Most studies to date have involved a relatively short period of follow-up ( $<3$ years), which may have been insufficient to detect late recurrences $(>5$ years). ${ }^{28}$ In the 5-year follow-up in the present study,

TABLE 2: Cumulative number of recurrences

\begin{tabular}{lcc}
\hline & $\begin{array}{l}\text { Negative margins } \\
(\mathbf{n = 9 0 )}\end{array}$ & $\begin{array}{l}\text { Positive margins } \\
(\mathbf{n = 2 1})\end{array}$ \\
\cline { 2 - 3 } $1^{\text {st }}$ year & 1 & 1 \\
$2^{\text {nd }}$ year & 4 & 3 \\
$3^{\text {rd }}$ year & 8 & 5 \\
$4^{\text {th }}$ year & 9 & 5 \\
$5^{\text {th }}$ year & 9 & 5 \\
\hline
\end{tabular}

most recurrences in patients with negative margins occurred in the third year $50 \%$ of all recurrences in cases of completely excised tumors), while in incompletely excised tumors most recurrences occurred in the second and third years following surgery ( $40 \%$ of all recurrences with positive margins in each year). These data are in agreement with findings reported in the literature. ${ }^{13}$

The time until the appearance of signs or symptoms of recurrence following incomplete resection was longer in men and in patients over 65 years of age. Males did not readily recognize the warning signs of BCC, probably because they are less likely compared to women to perform a self-examination of their skin. ${ }^{29}$ Gender was associated with recurrence rate in the present study, and recurrence was significantly more common in women with incompletely excised tumors. These data may be explained by the greater attention paid by women to their appearance and to more thorough and frequent self-examinations.

Boulinguez et al. ${ }^{15}$ concluded that initially nonaggressive, incompletely excised BCC do not require re-excision except if they are located in sites with a poor prognosis, in which case re-excision is mandatory.

In this study, older individuals, who were also less likely to perform self-examination of their skin, took longer to seek medical attention compared to younger people and in these cases morbidity was greater as a result of larger resections. ${ }^{29}$ For younger patients, the balance between the risk of scarring and 


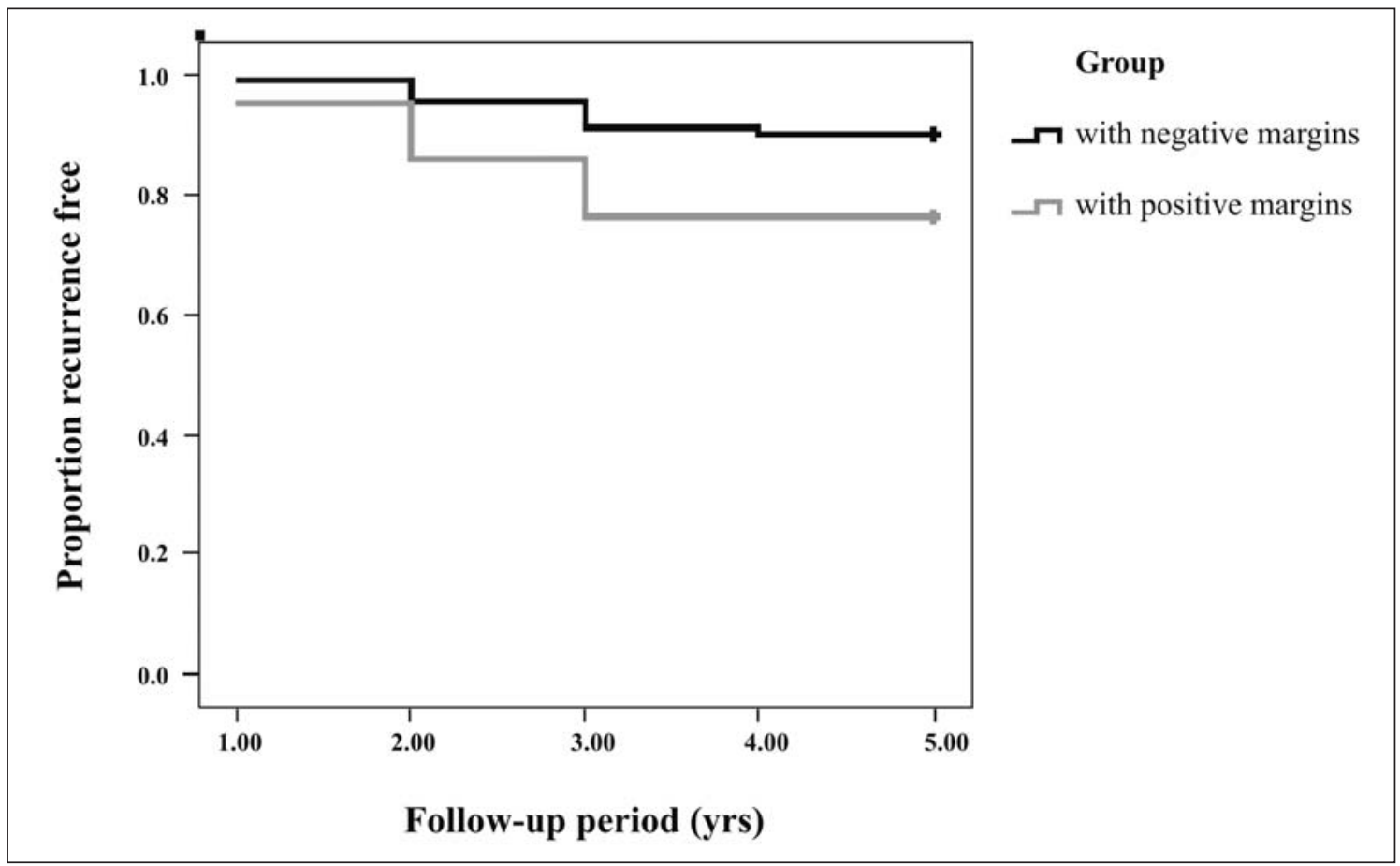

FIGURE 1: KaplanMeier survival analysis

the recurrence rate should be discussed prior to reexcision. ${ }^{15}$ In the present study, the mean age of patients with positive margins and recurrences (56.6 years) was significantly lower than that of the patients with positive margins and no recurrence (66.12 years), which appears to indicate that recurrence of incompletely excised BCC in the periorbital region is more common in younger individuals. Berlin et al.$^{30}$ recommended that when the patient is elderly, with multiple severe medical problems, then his/her quality of life, ability to tolerate further surgery and the risk of recurrence should all be taken into consideration and discussed with both the patient and his/her family if the tumor is a low-risk subtype with $4 \%$ or less involvement of the margins at the initial incomplete excision. Nevertheless, surgical margin control using Mohs micrographic surgery, when available, is probably a better way of avoiding re-excision when managing aggressive histopathologic types of BCC or when the BCC is situated at sites where the risk of recurrence is higher. ${ }^{15}$ However, Mohs technique is costly and laborintensive, often requiring numerous excisions and histological examinations. ${ }^{31}$ Furthermore, surgeons require specific training in the technique. In the present study, Mohs surgery was not performed.

When physicians receive a pathology report indicating that the excision of a BCC was incomplete, they face a dilemma regarding the future management of that patient. The practice of some experts in the field has been not to perform a second resection in cases of positive excision margins, since the probabi- lity of recurrence is limited. ${ }^{14}$ Berlin et al.$^{30}$ recommended clinical follow-up for patients with a very low risk of recurrence, while Nagore et al. ${ }^{11}$ recommended immediate re-excision in cases in which the resection margins were positive.

An individualized approach is recommended in the treatment of BCC, particularly in cases with positive margins. Special consideration should be given to the tumor site, and to the age and gender of the patient, since those with incompletely excised BCC of the medial canthus and those under 56 years of age have a significantly higher risk of recurrence, which is most likely to occur two to three years after surgery. Moreover, all cases require close monitoring, even those in which no residual tumor tissue is present at the resection margins. ${ }^{11}$

\section{CONCLUSION}

There is no statistically significant association between incomplete periorbital BCC excision and recurrence except when the tumor site is in the medial canthus.

In women and younger individuals, recurrences of periorbital BCC are significantly more common. Most of the recurrences occur in the first four years following excision. Incomplete BCC excision does not imply a certainty of recurrence. We would recommend re-excision of incompletely excised BCC in the medial cantus region particularly in the case of females and individuals under 56 years of age. 


\section{REFERÊNCIAS}

1. Cook BE, Bartley GB. Epidemiologic characteristics and clinical course of patients with malignant eyelid tumors in an incidence cohort in Olmstead County, Minnesota. Ophthalmology. 1999;106:746-50.

2. Atik B, Tan O, Bekerecioglu M, Cinal A, Tekes L. Reconstruction of lower eyelid defects using a cross upper eyelid flap composited with ear cartilage. Dermatol Surg. 2007;33:709-12.

3. Uhara H, Hayashi K, Koga H, Saida T. Multiple hypersonographic spots in basal cell carcinoma. Dermatol Surg. 2007;33:1215-9.

4. Braun RP, Klumb F, Girard C, Bandon D, Salomon D, Skaria A, et al. Three-dimensional reconstruction of basal cell carcinomas. Dermatol Surg. 2005;31:562-8.

5. Farhi D, Dupin N, Palangié A, Carlotti A, Avril MF. Incomplete excision of basal cell carcinoma: rate and associated factors among 362 consecutive cases. Dermatol Surg. 2007;33:1207-14.

6. Wolf DJ, Zitelli JA. Surgical margins for basal cell carcinoma. Arch Dermatol. 1987;123:340-4.

7. Glatt HJ, Olson JJ, Putterman AM. Conventional frozen sections in periocular basal-cell carcinoma: a review of 236 cases. Ophthalmic Surg. 1992;23:6-9.

8. Chalfin J, Putterman AM. Frozen section control in the surgery of basal cell carcinoma of the eyelid. Am J Ophthalmol. 1979;87:802-9.

9. Wettstein R, Erba P, Farhadi J, Kalbermatten DF, Arnold A, Haug M, et al. Incomplete excision of basal cell carcinoma in the subunits of the nose. Scand J Plast Reconstr Surg. 2008;42:92-5.

10. Griffiths RW. Audit of histologically incompletely excised basal cell carcinomas: recommendationsfor management by re-excision. $\mathrm{Br} \mathrm{J}$ Plast Surg. 1999;52:24-8.

11. Nagore E, Grau C, Molinero J, Fortea JM. Positive margins in basal cell carcinoma: relationship to clinical features and recurrence risk. A retrospective study of 248 patients. J Eur Acad Dermatol Venereol. 2003; 17:167-70.

12. Cohen PR, Schulze KE, Nelson BR. Basal cell carcinoma with mixed histology: a possible pathogenesis for recurrent skin cancer. Dermatol Surg. 2006;32:542-51.

13. Sussman LA, Liggins DF. Incompletely excised basal cell carcinoma: a mangement dilemma? Aust NZJ Surg. 1996;66:276-8.

14. Robinson JK, Fisher SG. Recurrent basal cell carcinoma after incomplete resection. Arch Dermatol. 2000;136:1318-24.

15. Boulinguez S, Grison-Tabone C, Lamant L, Valmary S, Viraben R, Bonnetblanc JM, et al. Histological evolution of recurrent basal cell carcinoma and thera peutic implications for incompletely excised lesions. $\mathrm{Br}$ J Dermatol. 2004;151:623-6.

16. Hsuan JD, Harrad RA, Potts MJ, Collins C. Small margin excision of periocular basal cell carcinoma: 5 year results. Br J Ophthalmol. 2004;88:358-60.

17. Cook BE Jr, Bartley GB. Treatment options and future prospects for the management of eyelid malignancies: an evidence-based update. Ophthalmology. 2001;108:2088-98.
18. Kumar P, Watson S, Brain AN, Davenport PJ, McWilliam LJ, Banerjee SS, et al. Incomplete excision of basal cell carcinoma: a prospective multicentre audit. Br J Plast Surg. 2002;55:616-22.

19. Wilson AW, Howsam G, Santhanam V, Macpherson D, Grant J, Pratt CA, et al. Surgical management of incompletely excised basal cell carcinomas of the head and neck. Br J Oral Maxillofac Surg. 2004;42:311-4.

20. Pieh S, Kuchar A, Novak P, Kunstfeld R, Nagel G, Steinkogler FJ. Long-term results after surgical basal cell carcinoma excision of the eyelid region. Br Ophthalmol. 1999;83:85-8.

21. Swetter SM, Yaghmai D, Egbert BM. Infiltrative basal cell carcinoma occurring in sites of biopsy-proven nodular basal cell carcinoma. J Cutan Pathol. 1998;25:420-5

22. De Silva SP, Dellon AL. Recurrence rate of positive margin basal cell carcinoma: results of a five-year prospective study. J Surg Oncol. 1985;28:72-4.

23. Dieu T, MacLeod AM. Incomplete excision of basal cell carcinomas: a retrospective audit. ANZ J Surg 2002;72:219-21.

24. Breuninger $H$, Pesch $M$, Dietz $K$, Rassner G. Quantitative analysis of recurrence and spontaneous regression of basalioma pars left in situ. Hautarzt.1992;43:561-5.

25. Dellon AL, DeSilva S, Connolly M, Ross A. Prediction of recurrence in incompletely excised basal cell carcinoma. Plast Reconstr Surg. 1985;75:860-71.

26. Spencer JM, Tannenbaum A, Sloan L, Amonette RA. Does inflammation contribute to the eradication of basal cell carcinoma following curettage and electrodesiccation? Dermatol Surg. 1997;23:625-31.

27. Nouri K, Spencer JM, Taylor JR, Hayag M, DeVoursney J, Shah N. Does wound healing contribute to the eradication of basal cell carcinoma following curettage and electrodesiccation? Dermatol Surg. 1999;25:183-8.

28. Wong VA, Marshall JA, Whitehead KJ, Williamson RM, Sullivan TJ. Management of periocular basal cell carcinoma using frozen section controlled excision. Ophthal Plast Reconstr Surg. 2002;18:430-5.

29. Robinson JK, Rigel DS, Amonette RA. What promotes skin self-examination? J Am Acad Dermatol. 1998;39:752-7.

30. Berlin J, Katz KH, Helm KF, Maloney ME. The significance of tumor persistence after incomplete excision of basal cell carcinoma. J Am Acad Dermatol. 2002;46:549-53.

31. Downes RN, Walker NPJ, Collin JRO. Micrographic (Mohs') surgery in the management of periocular basal cell epitheliomas. Eye. 1990;4:160-8.

ENDEREÇO PARA CORRESPONDÊNCIA / MAILING ADDRESS:

Blv. Zorana Djindjica - 48

Nis. 18000 Serbia and Montenegro

Celular +381637133261

Fone (Alt.) +38163258565

jankovic@jotel.co.rs

How to cite this article: Jankovic I, Kovacevic P, Visnjic M, Jankovic D, Binic I, Jankovic A. Does incomplete excision of basal cell carcinoma of the eyelid mean tumor recurrence? An Bras Dermatol. 2010;85(6):872-7. 